\title{
Sistem Komunikasi Fiber Optik Dan Pemanfaatannya Pada PT.Semen Padang
}

\author{
Hariyadi, M.Kom \\ Fakultas Teknik, Universitas Muhammadiyah Sumatera Barat \\ Email: hariyadi@umsb.ac.id
}

\begin{abstract}
Pada Era Globalisasi ini, Perkembangan Ilmu Pengetahuan Dan Teknologi (IPTEK) semakin berkembang dengan pesatnya,dimana akan menuntut Sumber Daya Manusia (SDM) yang unggul dan berkwalitas, sehingga dapat melaksanakan pekerjaan perindustrian secara efektif dan efisien.Fiber optik merupakan jaringan yang dapat mentransmisi cahaya. Dibandingkan dengan jenis lainnya, ini relatif mahal. Namun, fiber optik memiliki jangkauan yang lebih jauh dari 550 meter sampai ratusan kilometer, tahan terhadap interferensi elektromagnetik dan dapat mengirim data pada kecepatan yang lebih tinggi dari jenis lainnya. Fiber optik tidak membawa sinyal elektrik, seperti lainnya yang menggunakan tembaga. Tujuan penelitian ini adalah sistem komunikasi fiber optik dan pemanfaatannya pada PT.Semen Padang. Dengan adanya pemakaian jaringan fiber optik di PT.Semen Padang, dapat mempercepat proses kerja yang berlangsung.
\end{abstract}

Keywords: fiber optic, jaringan, cahaya, semen padang

\section{PENDAHULUAN}

\subsection{Latar Belakang}

Pada Era Globalisasi ini, Perkembangan Ilmu Pengetahuan Dan Teknologi (IPTEK) semakin berkembang dengan pesatnya,dimana akan menuntut Sumber Daya Manusia (SDM) yang unggul dan berkwalitas, sehingga dapat melaksanakan pekerjaan perindustrian secara efektif dan efisien. Sumber daya manusia ini merupakan faktor utama penentu dalam kemajuan perusahaan dan dunia perindustrian yang mempunyai kaitan yang sangat erat dengan dunia pendidikan. Sedangkan tenaga kerja yang dibutuhkan saat ini adalah tenaga kerja yang ulet dan professional dalam bidangnya. Dengan adanya penelitian ini, diharapkan dapat mengetahui terhadap situasi, kondisi, dan perubahan yang dinamis didalam lingkungan kerja.

\subsection{Perumusan Masalah}

Tujuan penelitian ini adalah sistem komunikasi fiber optik dan pemanfaatannya pada PT.Semen Padang

\section{LANDASAN TEORI}

\subsection{Fiber Optik}

Fiber optik merupakan jaringan yang dapat mentransmisi cahaya. Dibandingkan dengan jenis lainnya, ini relatif mahal. Namun, fiber optik memiliki jangkauan yang lebih jauh dari 550 meter sampai ratusan kilometer, tahan terhadap interferensi elektromagnetik dan dapat mengirim data pada kecepatan yang lebih tinggi dari jenis lainnya. Fiber optik tidak membawa sinyal elektrik, seperti lainnya yang menggunakan tembaga. Sebagai gantinya, sinyal yang mewakili bit tersebut diubah ke bentuk cahaya.

Perbandingan antar beberapa media transmisi

\begin{tabular}{|c|c|c|}
\hline Media & Kecepatan & Biaya \\
\hline Twisted Pair & $300 \mathrm{bps}-10 \mathrm{Mbps}$ & Rendah \\
\hline Coaxial Cable & $56 \mathrm{Kbps}-200 \mathrm{Mbps}$ & Rendah \\
\hline Microwave & $\begin{array}{l}256 \text { Kbps }-100 \\
\text { Mbps }\end{array}$ & Tinggi \\
\hline Satellite & $\begin{array}{l}256 \text { Kbps }-100 \\
\text { Mbps }\end{array}$ & Tinggi \\
\hline Fiber Optik & $500 \mathrm{Kbps}-6,4 \mathrm{Tbps}$ & Tinggi \\
\hline
\end{tabular}

Tabel 1. Perbandingan antara beberapa media transmisi.

\subsection{Struktur Fiber Optik}

Struktur dari fiber optik ini dapat diperlihatkan berikut ini : 


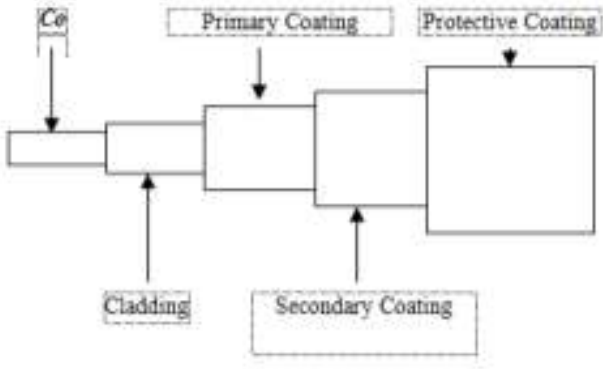

Gambar 2. Struktur Fiber Optik

Stuktur fiber optik biasanya terdiri atas 3 bagian, yaitu :

1) Bagian yang paling utama dinamakan inti (core)

Gelombang cahaya yang dikirim akan merambat dan mempunyai indeks bias lebih besar dari lapisan kedua, dan terbuat dari kaca. Inti (core) mempunyai diameter yang bervariasi antara $5-50$ $\mu \mathrm{m}$ tergantung jenis serat optiknya.

2) Bagian kedua dinamakan lapisan selimut/selubung (cladding )

Bagian ini mengelilingi bagian inti dan mempunyai indeks bias lebih kecil dibanding dengan bagian inti, dan terbuat dari kaca.

3) Bagian ketiga dinamakan jacket (coating)

Bagian ini merupakan pelindung lapisan inti dan selimut yang terbuat dari bahan plastik elastik.

\subsection{Jenis-jenis Serat Optik}

Serat optik terdiri dari 3 jenis, yaitu:

1) Multimode Step Index

Pada jenis multimode step index ini, diameter core lebih besar dari diameter cladding. Dampak dari besarnya diameter core menyebakan rugi-rugi dispersi waktu transmitnya besar. Penambahan prosentase bahan silica pada waktu pembuatan. Tidak terlalu berpengaruh dalam menekan rugirugi dispersi waktu transmit.

\section{2) Multimode Graded Index}

Pada jenis serat optik multimode graded index ini. Core terdiri dari sejumlah lapisan gelas yang memiliki indeks bias yang berbeda, indeks bias tertinggi terdapat pada pusat core dan berangsur-angsur turun sampai ke batas core-cladding. Akibatnya dispersi waktu berbagai mode cahaya yang merambat berkurang sehingga cahaya akan tiba pada waktu yang bersamaaan.
Multimode Graded Index mempunyai karakteristik sebagai berikut:

- Cahaya merambat karena difraksi yang terjadi pada core sehingga rambatan cahaya sejajar dengan sumbu serat.

- Dispersi minimum sehingga baik jika digunakan untuk jarak menengah.

- Ukuran diameter core antara $30 \mu \mathrm{m}-$ $60 \mu \mathrm{m}$. lebih kecil dari multimode step Index dan dibuat dari bahan silica glass.

- Harganya lebih mahal dari serat optik Multimode Step Index karena proses pembuatannya lebih sulit.

\section{3) Single Mode Step Index}

Pada jenis single mode step index. Baik core maupun claddingnya dibuat dari bahan silica glass. Ukuran core yang jauh lebih kecil dari cladding dibuat demikian agar rugi-rugi transmisi berkurang akibat fading.

Singlemode Step Index mempunyai karakteristik sebagai berikut:

- Serat optik Singlemode Step Index memiliki diameter core yang sangat kecil dibandingkan ukuran claddingnya.

- Ukuran diameter core antara $2 \mu \mathrm{m}-$ $10 \mu \mathrm{m}$.

- Cahaya hanya merambat dalam satu mode saja yaitu sejajar dengan sumbu serat optik.

- Memiliki redaman yang sangat kecil.

- Memiliki bandwidth yang lebar.

- Digunakan untuk transmisi data dengan bit rate tinggi.

- Dapat digunakan untuk transmisi jarak dekat, menengah dan jauh.

\subsection{Hukum Dasar Serat Optik}

Sistem komunikasi serat optik terkait dengan perambatan energi cahaya pada serat optik. Cara serat optik melewatkan cahaya bergantung dari sifat cahaya dan struktur serat optik yang dilewati. Dari sudut pandang telekomunikasi, cahaya adalah suatu bentuk energi yang merambat dalam bentuk gelombang. Itulah sebabnya, serat optik juga disebut optical waveguide, karena berfungsi sebagai pembimbing gelombang cahaya.

Cahaya merambat dalam dua medium berbeda dengan tiga cara yaitu merambat lurus, dibiaskan dan dipantulkan. Saat cahaya melintasi dua media yang berbeda, 
ada bagian cahaya yang dipantulkan kembali ke medium pertama dan sebagian lainnya dibiaskan.

\subsection{Kelebihan dan Kekurangan Fiber Optik \\ 2.5.1 Kelebihan}

Kelebihan yang dimiliki oleh kabel fiber optik dibanding yang lain antara lain:

1) Mempunyai lebar pita frekuensi (bandwith yang lebar).Frekuensi pembawa optik bekerja pada daerah frekuensi yang tinggi yaitu sekitar $10^{13}$ $\mathrm{Hz}$ sampai dengan $10^{16} \mathrm{~Hz}$, sehingga informasi yang dibawa akan menjadi banyak.

2) Redaman sangat rendah dibandingkan dengan kabel yang terbuat dari tembaga, terutama pada frekuensi yang mempunyai panjang gelombang sekitar 1300 nm yaitu $0,2 \mathrm{~dB} / \mathrm{km}$.

3) Kebal terhadap gangguan gelombang elektromagnet.

Fiber optik terbuat dari kaca atau plastik yang merupakan isolator, berarti bebas dari interferensi medan magnet, frekuensi radio dan gangguan listrik.

4) Dapat menyalurkan informasi digital dengan kecepatan tinggi. Kemampuan fiber optik dalam menyalurkan sinyal frekuensi tinggi, sangat cocok untuk pengiriman sinyal digital pada sistem multipleks digital dengan kecepatan beberapa Mbit/s hingga Gbit/s.

5) Ukuran dan berat fiber optik kecil dan ringan.

Diameter inti fiber optik berukuruan micro sehingga pemakaian ruangan lebih ekonomis.

6) Tidak mengalirkan arus listrik

Terbuat dari kaca atau plastik sehingga tidak dapat dialiri arus listrik (terhindar dari terjadinya hubungan pendek)

7) Sistem dapat diandalkan $(20-30$ tahun) dan mudah pemeliharaannya.

8) Low Cost dan Fleksible (kaku)

2.5.2 Kekurangan

Selain memiliki kelebihan, fiber optik juga memiliki kekurangan, diantaranya:
1. Konstruksi fiber optik lemah sehingga dalam pemakaiannya diperlukan lapisan penguat sebagai proteksi.

2. Karakteristik transmisi dapat berubah bila terjadi tekanan dari luar yang berlebihan

3. Tidak dapat dialiri arus listrik, sehingga tidak dapat memberikan catuan pada pemasangan repeater.

ANALISA DAN HASIL

\subsection{Sistem Komunikasi Fiber Optik}

Komunikasi dapatlah diartikan pentransferan informasi dari satu pihak ke pihak yang lain. Transfer informasi ini dilakukan dengan memodulasikan informasi pada gelombang elektromagnetik yang bertindak sebagai pembawa (carrier) sinyal informasi tersebut. Selanjutnya setelah tiba di tujuan, maka untuk memperoleh informasi yang asli dilakukan demodulasi.

Suatu komunikasi dikatakan berhasil atau sukses apabila dapat memuat informasi yang banyak dalam sekali pengiriman perdetiknya dan jarak yang dapat ditempuh oleh sinyal tersebut sehingga sinyal dapat diterima sesuai dengan terkirim. Serat optik merupakan salah satu alternatif sebagai media transmisi komunikasi yang cukup handal, karena ia memiliki keunggulan dibanding media lainnya.

Sistem komunikasi serat optis memanfaatkan cahaya sebagai gelombang pembawa informsi yang akan dikirimkan. Pada bagian pengirim isyarat informasi diubah menjadi isyarat optis. Lalu diteruskan ke kanal informasi yang juga terbuat dari serat optis bertugas sebagai pemandu gelombang. Sesampainya di penerima berkas cahaya ditangkap oleh detektor cahaya, yang berfungsi mengubah besaran optis menjadi besaran elektris. Di sini cahaya mengalami pelebaran dan pelemahan, disebabkan karena ketakmurnian bahan serat, yang menyerap serta menyebarkan cahaya.

Cahaya yang telah mengalami pelebaran dan pelemahan itu dapat dipulihkan kembali dengan memakai piranti pengulang elektronis, yang ditempatkan pada jarak tertentu. Prinsip kerja piranti ini adalah mengubah cahaya yang datang ke bentuk elektris kemudian diperkuat dan diubah 
kembali ke bentuk asal (cahaya). Akan tetapi hal ini dianggap kurang praktis, karena dapat menyebabkan kesalahan tambahan, membatasi pesat transmisi dan lebar bidang serta relatif mahal.

Perkembangan teknologi yang begitu pesat telah memunculkan penguat serat terdadah erbium (Erbium Doped Fiber Amplifier, EDFA). Penguat ini dapat mengurangi ketergantungan terhadap piranti pengulang yang biasa digunakan. Fungsi EDFA dalam sistem komunikasi optis adalah:

1) Penguat daya, berfungsi meningkatkan daya terpancar dari pengirim.

2) Pengulang, dipasang di tempattempat tertentu.

3) Penguat awal, berfungsi meningkatkan sensitivitas penerima.

Dengan menggunakan EDFA akan diperoleh pembangkitan sinyal dengan faktor yang lebih besar dan dapat membawa data dengan pesat bit yang lebih tinggi dibanding pengulang elektronik.

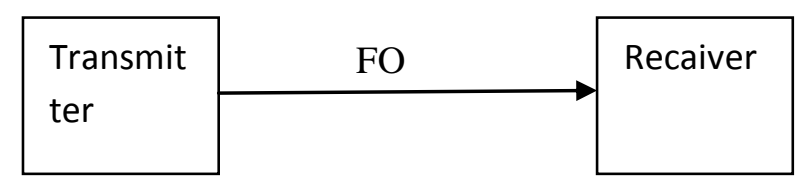

Gambar 3. Sistem dasar komunikasi fiber optik

Sistem Komunikasi Fiber optik terdiri dari 3 komponen utama yaitu:

a. Transmitter berupa Laser Diode ( LD ) dan Light Emmiting Diode (LED).

b. Media transmisi berupa fiber optic.

c. Receiver yang merupakan detektor penerima digunakan PIN dan APD.

\section{1) Transmitter} yaitu :

Transmitter terdiri dari 2 bagian

a) Rangkaian elektrik berfungsi untuk mengkonversi sinyal digital menjadi sinyal analog, selanjutnya data tersebut ditumpangkan kedalam sinyal gelombang optik yang telah termodulasi.

b) Sumber gelombang optik berupa sinar Laser Diode (LD) dan LED ( light emmiting diode ) yang pemakaiannya disesuaikan dengan sistem komunikasi yang diperlukan:
- Laser Diode dapat digunakan untuk sistem komunikasi optik yang sangat jauh seperti Sistem Komunikasi Kabel Laut (SKKL) dan Sistem Komunikasi Serat Optik (SKSO), karena laser LD mempunyai karakteristik yang handal yaitu dapat memancarkan daya dengan intensitas yang tinggi, stabil, hampir monokromatis, terfokus, dan merambat dengan kecepatan sangat tinggi, sehingga dapat menempuh jarak sangat jauh. Pembuatannya sangat sukar karena memerlukan spesifikasi tertentu sehingga harganyapun mahal. Jadi LD tidak ekonomis dan tidak efisien jika digunakan untuk sistem komunikasi jarak dekat dan pada trafik kurang padat.

- LED digunakan untuk sistem komunikasi jarak sedang dan dekat agar sistem dapat ekonomis dan efektif karena LED lebih mudah pembuatanya, sehingga harganyapun lebih murah.

\section{b) Recaiver}

Receiver atau bagian penerima terdiri dari 2 bagian yaitu detektor penerima dan rangakaian elektrik.

\section{a. Detektor penerima}

Berfungsi untuk mengkap cahaya yang berupa gelombang optik pembawa informasi, dapat berupa PIN diode atau APD (Avalance Photo Diode) pemilihannya tergantung keperluan sistem komunikasinya.Untuk komunikasi jarak jauh digunakan detektor APD yang dapat bekerja pada panjang gelombang $1300 \mathrm{~nm}, 1500 \mathrm{~nm}$ serta 1550 $\mathrm{nm}$ dengan kualitas yang baik. Artinya detector APD mempunyai sensitivitas dan response yang tinggi terhadap sinar laser LD sebagai pembawa gelombang optik informasi.

- Untuk komunikasi jarak pendek lebih efisien jika menggunakan ditektor PIN diode, karena PIN baik digunakan untuk bit rate rendah dan sensitivitasnya tinggi untuk LED. diode dan dapat dianalisis sebagai berikut:

- Sumber cahaya LD terlihat memiliki daya lebih besar, stabil, konstan pada bit rate berapapun, sedangkan sumber cahaya LED mempunyai daya pancar yang lebih kecil dan pada bit rate 100 Mbps dayanya mulai menurun.

\begin{tabular}{lr}
\hline 46 & Fakultas Teknik UMSB \\
EISSN 2599-2081 2599-2090
\end{tabular}


- Detektor penerima PIN bereaksi baik pada bit rate rendah tetapi kurang sensitif bila bit rate dinaikan.

- Detektor penerima APD lebih sensitif pada bit rate tinggi. Untuk transmisi jarak jauh diperlukan daya pancar yang lebih besar dan sensitifitas yang tinggi, sistem fiber optik akan menggunakan laser LD sebagai sumber cahaya dan APD sebagai detektor penerima. Sedangkan untuk transmisi jarak dekat cukup digunakan LED sebagai sumber optik dan PIN sebagai ditektor penerima.

b. Rangkaian elektrik

Berfungsi untuk mengkonversi cahaya pembawa informasi terhadap data informasi terhadap data informasi yang dibawa dengan melakukan regenerasi timing, regenerasi pulse serta konversi sinyal elektrik ke dalam interfaceV.28 yang berupa sinyal digital dan sebaliknya.

Blok diagaram sistem komunikasi serat optik secara umum, dimana fungsi-fungsi dari setiap bagian adalah sebagai berikut :

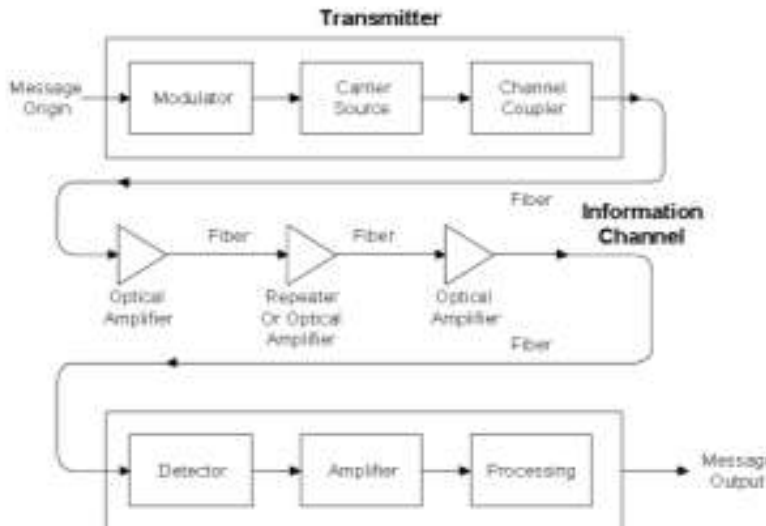

Gambar 4.Blok diagnam sistem komunikasi serat optik secara umum.

\section{1) Message Origin}

Message origin bisa berupa besaran fisik non-listrik (suara atau gambar), sehingga diperlukan transduser (sensor) yang merubah message dari bentuk non-listrik ke bentuk listrik.

Contoh yang umum adalah microphone merubah gelombang suara menjadi arus listrik dan Video Camera (CCD) merubah gambar menjadi arus listrik.

\section{2) Modulator dan Carrier Source (Pembawa sumber)}

Memiliki 2 fungsi utama, pertama merubah message elektrik ke dalam bentuk yang sesuai, kedua menumpangkan sinyal ini pada gelombang yang dibangkitkan oleh carrier source.

Format modulasi dapat dibedakan menjadi modulasi analog dan digital. Pada modulasi digital untuk menumpangkan sinyal data digital pada gelombang carrier, modulator cukup hanya meng-on kan atau meng-off kan carrier source sesuai dengan sinyal data-nya. Carrier source membangkitkankan gelombang cahaya dimana padanya informasi ditransmisikan, yang umum digunakan Laser Diode (LD) atau Light Emitting Diode (LED).

\section{3) Channel Coupler}

Untuk menyalurkan power gelombang cahaya yang telah termodulasi dari carrier source ke information channel (serat optik).Merupakan bagian penting dari desain sistem komunikasi serat optik sebab kemungkinan loss yang tinggi.

\section{4) Information Channel (Serat Optik)}

Karakteristik yang diinginkan dari serat optik adalah atenuasi yang rendah dan sudut light-acceptance-cone yang besar.Amplifier dibutuhkan pada sambungan yang sangat panjang (ratusan atau ribuan kilometer) agar didapatkan power yang cukup pada receiver.

Repeater hanya dapat digunakan untuk sistem digital, dimana berfungsi merubah sinyal optik yang lemah ke bentuk listrik kemudian dikuatkan dan dikembalikan ke bentuk sinyal optik untuk transmisi berikutnya.

Waktu perambatan cahaya di dalam serat optik bergantung pada frekuensi cahaya dan pada lintasan yang dilalui, sinyal cahaya yang merambat di dalam serat optik memilki frekuensi berbeda-beda dalam rentang tertentu (lebar spektrum frekuensi) dan powernya terbagi-bagi sepanjang lintasan yang berbeda-berbeda, hal ini menyebabkan distorsi pada sinyal.

Pada sistem digital distorsi ini berupa pelebaran (dispersi) pulsa digital yang merambat di dalam serat optik, pelebaran ini makin bertambah dengan bertambahnya 
jarak yang ditempuh dan pelebaran ini akan tumpang tindih dengan pulsa-pulsa yang lainnya, hal ini akan menyebabkan kesalahan pada deteksi sinyal. Adanya dispersi membatasi kecepatan informasi (pada system digital kecepatan informasi disebut data rate diukur dalam satuan bit per second (bps) yang dapat dikirimkan.Pada fenomena optikal soliton, efek dispersi ini diimbangi dengan efek nonlinier dari serat optik sehingga pulsa sinyal dapat merambat tanpa mengalami perubahan bentuk (tidak melebar).

\section{5) Detector dan Amplifier}

Digunakan foto-detektor (photo-diode, photo transistor dsb) yang berfungsi merubah sinyal optik yang diterima menjadi sinyal listrik.

\section{6) Signal Processor}

Untuk transmisi analog, sinyal prosesor terdiri dari penguatan dan filtering sinyal. Filtering bertujuan untuk memaksimalkan rasio dari daya sinyal terhadap power sinyal yang tidak diinginakan. Fluktuasi acak yang ada pada sinyal yang diterima disebut sebagai noise. Bagaimana pengaruh noise ini terhadap system komunikasi ditentukan oleh besaran SNR (Signal to Noise Ratio), yaitu perbandingan daya sinyal dengan daya noise, biasanya dinyatakan dalam desi- Bell (dB), makin besar SNR maka makin baik kualitas sistem komunikasi tersebut terhadap gangguan noise.

Untuk sistem digital, sinyal prosesor terdiri dari penguatan dan filtering sinyal serta rangkaian pengambil keputusan .

Rangkaian pengambil keputusan ini memutuskan apakah sebuah bilangan biner 0 atau 1 yang diterima selama slot waktu dari setiap individual bit. Karena adanya noise yang tak dapat dihilangkan maka selalu ada kemungkinan kesalahan dari proses pengambilan keputusan ini, dinyatakan dalam besaran Bit Error Rate(BER) yang nilai-nya harus kecil pada komunikasi.

Jika data yang dikirim adalah analog (misalnya suara), namun ditransmisikan melalui serat optik secara digital (pada transmitter dibutuhkan Analog to DigitalConverter (ADC) sebelum sinyal masuk modulator) maka dibutuhkan juga Digital to Analog Converter (DAC) pada sinyal prosesor, untuk merubah data digital menjadi analog, sebelum dikeluarkan ke output (misalnya speaker).

\section{7) Message Output}

Jika output yang dihasilkan di presentasikan langsung ke manusia, yang mendengar atau melihat informasi tersebut, maka output yang masih dalam bentuk sinyal listrik harus dirubah menjadi gelombang suara atau visual image. Transduser (actuator) untuk hal ini adalah speaker untuk audio message dan tabung sinar katoda (CRT) (atau yang lainnya seperti $L C D$, OLED dsb) untuk visual image.

Pada beberapa situasi misalnya pada sistem dimana komputer-komputer atau mesin-mesin lainnya dihubungkan bersamasama melalui sebuah sistem serat optik, maka output dalam bentuk sinyal listrik langsung dapat digunakan. Hal ini juga jika sistem serat optik hanya bagian dari jaringan yang lebih besar, seperti pada sebuah fiber link antara telephone exchange atau sebuah fiber trunk line membawa sejumlah progam televisi, pada kasus ini prosesing mencakup distribusi dari sinyal listrik ke tujuan-tujuan tertentu yang diinginkan. Peralatan pada message ouput secara sederhana hanya berupa sebuah konektor elektrik dari prosesor sinyal ke sistem berikutnya.

Keunggulan-Keunggulan Transmisi Serat Optik dibanding transmisi lainnya antara lain:

1) Redaman Transmisi yang kecil.

2) Range Frekuensi yang lebar.

3) Ukuran lebih kecil, simple dan ringan.

4) Bebas Interferensi Elektromagnetik

3.2 Pemasangan Jaringan LAN dengan Fiber Optik di PT. Semen Padang

Jaringan LAN pada PT. Semen Padang menggunankan media kabel optik dan kabelUTP. Untuk kabel optik pemasangannya memang agak sulit, jaringan yang dipasang merupakan bentuk dari Star.

Alat-alat yang terkait dengan jaringan LAN yang menggunakan fiber optik ini adalah:

a) Workstation

Adalah sebuah komputer dengan CPU yang berfungsi sebagai media kerja bagi karyawan dalam pengelolahan data dan bekerja seabgai komunikasi data antar 
komputer dengan komputer, dan komputer dengan server.

b) Hub (konektor)

Merupakan media pembagi jaringan yang digunakan melalui kabel UTP ke masing-masing workstation dan dari workstation dihubungkan ke hubungan yang berfungsi sebagai penghubung dan pembagi.

c) UTP Kabel

Adalah kabel khusus buat transmisi data. UTP (Unshielded Twisted Pair) disebut Unshielded karena kurang tahan terhadap interferensi elektromagnetik, dan disebut twisted pair karena didalamnya terdapat pasangan kabel yang disusun spiral (saling berlilitan).

d) Swich hub

Swict hub adalah media yang menghubungkan hubungan ke server. Fungsinya sebagai media pembagi jaringan dengan tidak mengurangi band width data, dimana swict hub bisa menghubungkan antar workstation-workstation, hub to hub dan workstation ke server.

e) Wallmount

Merupakan panel dinding/media conncting, yang bisa dikatakan sebagai titk sambung dari wallmount yang ada diarea unit kerja lain.

f) Server

Fungsinya sebagai bank data yang merupakan program aplikasi tempat menampung seluruh data yang dikirim dari biro-biro yang menggunakan jaringan ini dan sebagai tempat untuk memproses data yang diterima maupun yang dikirim.

\subsubsection{Jaringan fiber optik pada kantor Bagonjong}

Fiber optik di kantor Bagonjong menggunakan satu Router Merek ATI X900XS24 yang berfungsi sebagai Routing Utama untuk Area Pabrik, kemudian untuk komunikasi antar Lokasi di Area Pabrik dihubungkan oleh Kabel FO 8 Core dan 4 Core dan diterima oleh Switch 8000s di masing-masing lokasi :

1) CCS Indarung $\mathrm{V}$ dilantai 2 menggunakan switch ATI $8000 \mathrm{~S}$ dan ATI 8024G, Switch 8024G juga berfungsi untuk VLAN Access Point dari Kantor Pusat yang juga memakai FO 4 Core yang lama (Existing) .

2) CCP Indarung IV dengan menggunakan kabel 8 core dan terdapat satu switch 8000 S untuk menghubungkan ke jaringan LAN yang ada diruang tersebut.

3) CCR Indarung II/III dengan kabel optik 8 core, yang terdapat dua switch 8000 s untuk menghubungkan ke jaringan LAN yang ada diruang tersebut, Switch 8000S juga berfungsi untuk VLAN Access Point dari Kantor Pusat dengan koneksi memakai FO 4 Core Multimode yang lama (Existing).

4) Kantor Gonjong (PTP) dengan kabel optik 4 core, yang terdapat 1 switch 8000s yang terhubung ke LAN untuk penggunaan komputer di ruangan tersebut.

5) Adm. Kantor Gonjong dengan menggunakan kabel optik 4 core. Yang terdapat 2 switch yang mengubungkan ke masing-masing komputer di ruangan tersebut.

6) GI dengan menggunakan kabel optik 4 core dari DB 158 dan menggunakan kabel 8 core ke Kantor Gonjong mengubungkan ke masing-masing komputer di ruangan tersebut.

7) Elektrikal / PLTD dengan menggunakan kabel optik 8 core dari Kantor Gonjong menghubungkan ke masing-masing komputer di ruangan tersebut.

\subsubsection{Jaringan Fiber kantor Tambang}

Pemasangan jaringan Fiber Optik pada kantor Tambang terhubung dari ruang Data Center yang berada pada kantor pusat lantai V. Pada kantor Tambang jaringan fiber Optik di teruskan ke Wallmount yang berada di Silo Batu Gadang dan baru diteruskan ke kantor tambang dengan menggunakan kabel Fiber Optik 8 core. Di kantor Tambang terdapat 2 switch yang yang menghhubungkan ke jaringan LAN untuk diteruskan ke komputer di kantor tersebut.Untuk jaringan Fiber Optik Ke Workshop PAT dari Wallmount di Batu Gadang, yang perangkat tersebut terletak di Ruang PABX Batu Gadang. 


\subsubsection{Jaringan Fiber pada kantor Komunikasi}

Pemasangan jaringan fiber optik di kantor komunikasi terhubung dari Data Center, dengan menggunakan kabel optik 8 core, lalu diterima oleh Switch 8000s yang berada di kantor komunikasi. Di kantor komunikasi terdapat Satu switch yang nantinya terhubung ke masing-masing komputer yang ada dikantor tersebut. Selain itu dari Switch yang berada di kantor komunikasi juga diteruskan ke Workshop Febrikasi dengan kabel optik 4 core, di workshop ferbrikasi terdapat 1 switch yang terhubung nantinya ke komputer yang ada disana.

\subsubsection{Jaringan Fiber pada kantor Litbang}

Pemasangan jaringan fiber optik di kantor Litbang, juga dari Data Center yang berada di Kantor Pusat diteruskan ke Router ATI 9924 yang berada di Ruangan Server Litbang dengan menggunakan kabel optik 4 core, yang akan diteruskan ke Switch di:

1) Kantor PU, dengan menggunakan kabel optik 8 core. Dimana di kantor tersebut terdapat 2 swict 8000 S yang akan diteruskan untuk jaringan LAN dikantor tersebut.

2) Kantor Diklat dengan menggunakan kabel optik 4 core, Dimana di kantor tersebut terdapat 2 switch yang akan diteruskan untuk jaringan LAN dikantor tersebut.

3) WI diteruskan ke WP dengan kabel optik 8 core. Dimana di WI terdapat 1 switch untuk menghubungkan ke komputer yang ada di kantor tersebut yang berada di bukit ngalau.

\subsubsection{Jaringan Fiber Pada kantor PPI}

Pemasangan jaringan fiber optik di kantor PPI , lanjutan dari Data Center yang berada di Kantor Pusat diteruskan ke Router ATI 9924 yang berada di Ruangan Server PPI dengan menggunakan kabel optik Singlemode 4 core, dan Multimode 4 core selanjutnya diteruskan ke Switch di Timbangan Clay menggunakan swict 8024 dengan memanfaatkan kabel fiber optik 4 core

\subsection{Maintenance}

Dalam pemeliharaan jaringan fiber optik yang dilakukan PT.Semen Padang adalah dengan menjaga kestabilan suhu dari alat-alat yang terkait dalam pengiriman data dan untuk pemeliharaan fiber optik, PT.Semen Padang melindungi kabel melalui loteng dan selokon dengan paralon.

\subsection{Keuntungan dan Kerugian PT.Semen Padang setelah menggunakan Jaringan Fiber Optik \\ 3.4.1 Keuntungan}

Berikut adalah beberapa keuntungan yang didapat oleh PT. Semen Padang setelah menggunakan fiber optik:

1) Dengan kapasitas penyaluran informasi yang besar, dapat memperlancar urusan komunikasi dan pengolahan data disetiap birobiro PTSP yang menggunakan jaringan Fiber Optik.

2) Ringan, kecil dan kompak, dapat digunakan untuk kabel komunikasi sehingga lebih aman dan memudahkan dalam pengangkutan kabel.

3) Bandwitdh yang lebar dan frekwensi yang jauh lebih tinggi, dapat mempercepat jalannya komunikasi data yang berada di wilayah perusahaan yang menggunakan jaringan fiber optik.

4) Jaringan bisa dipakai lebih banyak sekaligus.

5) Karena fiber optik tidak mengantarkan arus listrik, sehingga tahan terhadap arus bolak balik lewat tanah.

\subsubsection{Kerugian}

Selain mendapatkan keuntungan PT. Semen Padang juga mendapatkan kendala, diantara kendala yang dihadapi adalah:

1) Harga mahal.

2) Mudah patah (getas), serta biaya perbaikan yang mahal.

\section{PENUTUP}

\subsection{Simpulan}

1) Fiber optik merupakan jaringan yang dapat mentransmisi cahaya. Dibandingkan dengan jenis lainnya, 
ini relatif mahal. Namun, fiber optik memiliki jangkauan yang lebih jauh dari 550 meter sampai ratusan kilometer, tahan terhadap interferensi elektromagnetik dan dapat mengirim data pada kecepatan yang lebih tinggi dari jenis lainnya.

2) Struktur dasar dari sebuah serat optik yang terdiri dari 3 bagian : core (inti), cladding (kulit), dan coating (mantel) atau buffer (pelindung).

3) Sistem komunikasi optik secara umum terdiri dari Transmitter (Message origin, Modulator, Carrier Source dan Channel Coupler), Information Channel (Serat Optik) dan Receiver (Detector, Amplifier, Signal Processor dan MessageOutput).

4) Serat optik terdiri dari 3 jenis, yaitu:Multimode Step Index, Multimode Graded Index, Single Mode Step Index.

5) Dengan adanya kemudahan jaringan LAN dan pemanfaatan fiber optik sebagai transmisi data dan aplikasi yang tersedia, memudahkan dalam hubungan komunikasi data tanpa harus mengecek langsung ke lokasi.

6) Dengan adanya pemakaian jaringan fiber optik di PT.Semen Padang, dapat mempercepat proses kerja yang berlangsung.

\subsection{Saran}

1) Dalam pemeliharaan jaringan fiber optik, sebaiknya dilakukan secara rutin dalam periode yang telah ditetapkan.

2) Untuk dapat terus meningkatkan terus teknologi sistem informasi terutama jaringan fiber optik di perusahaan.

\section{UCAPAN TERIMA KASIH}

Alhamdulillah dengan rahmat Allah penulis dapat menyelesaikan penelitian ini. Terimakasih untuk keluarga, dan FT.UMSB atas dukungan dan doa.

\section{DAFTAR PUSTAKA}

Faiz, M. 1999. Power Budget Analysis Of Broadcast Passive Optical Network. Tesis padaUniversiti Teknologi Tun Hussein Onn
Praja, F G. Aryanta, D. Lidyawati, L. 2011. Analisis Perhitungan dan Pengukuran Transmisi Jaringan Serat Optik Telkomsel Regional Jawa Tengah.

Wadhana, Kusuma, E. dan Setijono, H. 2008. Analisa Redaman Serat Optik Terhadap Kinerja Sistem Komunikasi Serat Optik Menggunakan Metode Optical Link Power Budget.

Keiser, G. 2006. FTTX concepts and applications. New Jersey: Jonh Wiley \& Son,Inc.

Telkom Indonesia, P.T. 2004. Optical Access Network. Bandung: PT Telekomunikasi Indonesia, Tbk.

Telkom Indonesia, P.T. 2013. Operation Maintenance Jaringan FTTH. Bandung: PT Telekomunikasi Indonesia, Tbk.

Hariyadi, S., and M. Kom. "PEMANFAATAN MODEM ADSL DALAM KOMUNIKASI DATA DAN JARINGAN INTERNET PADA GEDUNG BAGONJONG DAN INDARUNG 5 DI LINGKUNGAN PT. SEMEN PADANG." Menara Ilmu 12.1 (2018).

Telkom Indonesia, P.T. 2013. Pedoman Desain Jaringan FTTH. Bandung: PT Telekomunikasi Indonesia, Tbk.

Telkom Indonesia, P.T. 2013. Pedoman Pemasangan Instalasi Jaringan FTTH. Bandung: PT Telekomunikasi Indonesia, Tbk.

Nugroho, A. 2011. Teknologi GigabitCapabel Passive Optical Network (GPON) Sebagai Triple Play Service. Makalah Seminar Kerja Praktek, Teknik Elektro Universitas Diponegoro. 